\title{
Correlation and Path Coefficient Analysis in Blackgram [Vigna mungo (L.) Hepper] Across Seasons
}

\author{
Sidramappa* , P. H. Kuchanur, M. Shobharani, B. Arunkumar, \\ S. A. Kulkarni, H. C. Sowmya, D. Sheela, Laxuman and S. Bharati \\ University of Agricultural Sciences, Raichur-585401, Karnataka, India \\ *Corresponding author
}

\begin{abstract}
A B S T R A C T
Information on the mutual association of traits is important for effective selection in plant breeding programme. In present investigation, a number of phenological and other yield components traits and their relationship with yield as well as among themselves was examined using correlation analysis. Twenty-five blackgram genotypes of diverse nature including two local checks were evaluated during kharif and summer seasons across three locations to study the nature of association and direct and indirect effects of phenological and yield component traits on seed yield per plant. The data obtained over six environments were subjected to correlation and path coefficient analysis on pooled basis. Out of 10 characters six characters viz., plant height, number branches per plant, number of pods per plant, clusters per plant, pod length and 100-seed weight were highly significant and positively correlated with seed yield across seasons. The important yield related traits like branches per plant, pods per plant and clusters per plant exhibited significant positive association among themselves. The characters which showed high positive correlation with yield like branches per plant, clusters per plant, pods per plant showed high positive direct effects on yield. These results implied the association of these characters with yield is more valuable. Moreover, the indirect effects of these characters through each other are also positive and high indicating the inter-dependent interactions of these characters to form yield.
\end{abstract}

Keywords

Blackgram,

Genotype, Seed yield, Association, Correlation, Path coefficient

Article Info

Accepted:

07 September 2020

Available Online:

10 October 2020

\section{Introduction}

Pulses are indispensable source of protein for predominantly vegetarian population of our country and they constitute a major part in our daily diet. Pulses are also known to increase the soil fertility and productivity of succeeding crop. Blackgram [Vigna mungo (L.) Hepper] is third most important pulse crop both in acreage and production it is grown over an area of 4.49 million ha with an annual production of 2.93 million tonnes (Anon., 2017). Seed yield is a complex quantitative trait that is influenced by a number of yield contributing characters. Development of improved cultivar with capability of producing better yield under various agro-climatic conditions depends upon the amount of genotypic variability present in a population for the traits. 
Correlations are of value to indicate the degree to which various characters are associated with productivity. A correlation coefficient is useful in quantifying the magnitude and direction of components influence in the determination of main characters. However, it did not provide the relative importance of direct and indirect effects of such components. Selections based on simple correlation coefficients without considering interactions among yield and yield components may mislead the breeders to reach their main breeding purposes.

Path analysis can be used to calculate the quantitative impact on seed yield through direct and indirect effects caused by one or the other component traits. It provides an effective means of partitioning correlation coefficients into direct and indirect effects and illuminates the relationship in a more meaningful way. Path analysis thus permits a critical examination of specific factors that produce a given correlation and can be successfully employed in formulating an effective selection strategy. So far, many studies on trait associations of blackgram have been done generally for particular season and not across the different seasons/environments. Keeping all these things in view, investigations were carried on a set of selected blackgram genotypes to assess the relationship between yield and yield components and to determine the direct and indirect effects of different yield-related traits on seed yield and evolve a suitable selection strategy for seed yield improvement.

\section{Materials and Methods}

The study material for the present investigation consisted of 25 blackgram genotypes collected from different sources viz., Agricultural Research Station, Bidar; Nuclear Agriculture and Biotechnology Division, BARC, Trombay, Mumbai; Indian
Institute of Pulse Research, regional station, Dharwad and Regional Agricultural Research Station, LAM, Guntur. They were evaluated during kharif-2018 and summer-2019 across three locations viz., Agricultural Research Station, Bidar, Agricultural Research Station, Kalaburagi and Agricultural Research Station, Bheemarayanagudi. The experimental trial was laid out in Randomized Block Design with two replications. Each genotype in each replication was represented by a plot size of 4 rows of 4 meter length with a spacing of 30 $\mathrm{cm}$ between rows and $10 \mathrm{~cm}$ between plants within a row. All the recommended agronomic practices were followed to raise a good crop. Observations on 11 quantitative traits were recorded. Observations on plant height, branches per plant, clusters per plant, pods per plant, seeds per pod, pod length, 100 -seed weight and seed yield per plant were recorded on five competitive plants selected at random per genotype in each replication. Whereas, observations on days to 50 per cent flowering, days to maturity and reproductive period were recorded on plot basis. Days to 50 per cent flowering was recorded as number of days from sowing to the opening of the flower in 50 per cent of the plants, days to maturity was recorded as number of days from sowing to 50 per cent pod maturity and reproductive period was recorded as number of days from flowering to maturity in each of the genotype. The data obtained over six environments were subjected pooled correlation analysis (Burton and Devane, 1953) and path coefficient analysis (Dewey and $\mathrm{Lu}, 1959$ ).

\section{Results and Discussion}

The analysis of variance revealed highly significant differences among the genotypes for all the traits suggesting presence of sufficient variability in the material used for the investigation (Table 1). 
Table.1 Pooled ANOVA for 11 quantitative traits in selected 25 genotypes of blackgram

\begin{tabular}{|c|c|c|c|c|c|c|c|c|c|c|c|c|}
\hline Source of Variations & df & $\begin{array}{c}\text { Days to } \\
50 \% \\
\text { flowerin } \\
\mathrm{g}\end{array}$ & $\begin{array}{l}\text { Days to } \\
\text { maturity }\end{array}$ & $\begin{array}{l}\text { Reprodu } \\
\text { ctive } \\
\text { period }\end{array}$ & $\begin{array}{c}\text { Plant } \\
\text { height } \\
\text { (cm) }\end{array}$ & $\begin{array}{l}\text { Number } \\
\text { of } \\
\text { branches } \\
\text { per plant }\end{array}$ & $\begin{array}{l}\text { Number } \\
\text { of pods } \\
\text { per plant }\end{array}$ & $\begin{array}{c}\text { Number } \\
\text { of } \\
\text { clusters } \\
\text { per plant }\end{array}$ & $\begin{array}{l}\text { Number } \\
\text { of seeds } \\
\text { per pod }\end{array}$ & $\begin{array}{c}\text { Pod } \\
\text { length } \\
\text { (cm) }\end{array}$ & $\begin{array}{l}\text { 100- seed } \\
\text { weight } \\
\text { (g) }\end{array}$ & $\begin{array}{c}\text { Seed } \\
\text { yield per } \\
\text { plant (g) }\end{array}$ \\
\hline Varieties & 24 & $3.38 * *$ & $15.73 * *$ & $13.42 * *$ & $44.69 * *$ & $0.46 * *$ & $48.38 * *$ & $2.07 *$ & 0.18 & 0.07 & $0.67 * *$ & $4.52 * *$ \\
\hline Environments & 5 & $24.12 * *$ & $121.01 * *$ & $123.77 * *$ & $242.35 * *$ & $27.46 * *$ & $322.08 * *$ & $84.36 * *$ & $11.71 * *$ & $2.89 * *$ & $2.40 * *$ & $42.59 * *$ \\
\hline Env.+ (Var. x Env.) & 125 & $2.76 * *$ & $12.60 * *$ & $13.24 * *$ & $30.77 *$ & $1.31 * *$ & $25.44 * *$ & $4.39 * *$ & $0.59 * *$ & $0.19 * *$ & $0.17 * *$ & $2.67 * *$ \\
\hline Pooled Error & 144 & 0.00 & 0.00 & 0.00 & 3.28 & 0.09 & 2.60 & 0.16 & 0.09 & 0.03 & 0.01 & 0.20 \\
\hline
\end{tabular}

Table.2 Phenotypic correlation coefficients between different traits in blackgram genotypes in pooled analysis

\begin{tabular}{|c|c|c|c|c|c|c|c|c|c|c|c|}
\hline & DFF & DM & RP & PHT & NBP & NPP & NCP & NSP & PL & HSW & SYPP \\
\hline DFF & 1.000 & $0.461 *$ & 0.005 & -0.056 & 0.188 & 0.058 & -0.012 & -0.076 & $0.599 * *$ & -0.035 & 0.094 \\
\hline DM & & 1.000 & $0.889 * *$ & 0.009 & 0.076 & -0.020 & -0.051 & 0.306 & -0.032 & 0.044 & -0.049 \\
\hline $\mathbf{R P}$ & & & 1.000 & 0.039 & -0.011 & -0.053 & -0.052 & 0.384 & -0.345 & 0.068 & -0.104 \\
\hline NBP & & & & & 1.000 & $0.963 * *$ & $0.967 * *$ & 0.307 & $0.527 * *$ & $0.514 * *$ & $0.956 * *$ \\
\hline NPP & & & & & & 1.000 & $0.965 * *$ & 0.281 & $0.623 * *$ & $0.544 * *$ & $0.985 * *$ \\
\hline PL & & & & & & & & & 1.000 & 0.023 & $0.842 * *$ \\
\hline HSW & & & & & & & & & & 1.000 & $0.546 * *$ \\
\hline SYPP & & & & & & & & & & & 1.000 \\
\hline
\end{tabular}

* Significant at $5 \%$ probability ** Significant at $1 \%$ probability

DFF - Days to $50 \%$ flowering NPP - Number of pods per plant

DM - Days to maturity NCP - Number of clusters per plant

SYPP - Seed yield per plant $(\mathrm{g})$

RP - Reproductive period

NSP - Number of seeds per pod

PHT - Plant height $(\mathrm{cm})$

PL - Pod length $(\mathrm{cm})$

NBP - Number of branches per plant $\quad$ HSW - Hundred seed weight $(\mathrm{g})$ 
Table.3 Direct and indirect effects of 10 yield components on seed yield per plant at phenotypic level in blackgram in pooled analysis

\begin{tabular}{|c|c|c|c|c|c|c|c|c|c|c|c|}
\hline & DFF & $\mathbf{D M}$ & $\mathbf{R P}$ & PHT & NBP & NPP & NCP & NSP & PL & HSW & rp \\
\hline DFF & 0.1451 & 0.0669 & 0.0007 & -0.0082 & 0.0272 & 0.0084 & -0.0017 & -0.0110 & 0.0869 & -0.0050 & 0.094 \\
\hline DM & -0.1162 & -0.2518 & -0.2240 & -0.0022 & -0.0192 & 0.0051 & 0.0129 & -0.0770 & 0.0081 & -0.0111 & -0.049 \\
\hline $\mathbf{R P}$ & 0.0008 & 0.1437 & 0.1616 & 0.0062 & -0.0018 & -0.0085 & -0.0083 & 0.0620 & -0.0557 & 0.0109 & -0.104 \\
\hline PHT & -0.0449 & 0.0068 & 0.0308 & 0.7980 & 0.4421 & 0.5474 & 0.5855 & 0.4490 & 0.8416 & 0.4265 & $0.723^{* *}$ \\
\hline NBP & 0.1178 & 0.0477 & -0.0069 & 0.3473 & 0.6270 & 0.6312 & 0.6061 & 0.1924 & 0.3304 & 0.3222 & $0.956 * *$ \\
\hline NPP & 0.1137 & -0.0397 & -0.1034 & 1.3472 & 1.9772 & 1.9639 & 2.0290 & 0.5508 & 1.2234 & 1.0674 & $0.985^{* *}$ \\
\hline NCP & 0.0127 & 0.0545 & 0.0548 & -0.7811 & -1.0291 & -1.0999 & -1.0646 & -0.2634 & -0.7751 & -0.7481 & $0.895^{* *}$ \\
\hline NSP & 0.0266 & -0.1076 & -0.1351 & -0.1981 & -0.1081 & -0.0988 & -0.0871 & -0.3521 & -0.3762 & 0.1818 & 0.373 \\
\hline PL & -0.1403 & 0.0076 & 0.0808 & -0.2471 & -0.1235 & -0.1459 & -0.1705 & -0.2503 & -0.2343 & -0.0053 & $0.842 * *$ \\
\hline HSW & 0.0181 & -0.0231 & -0.0354 & -0.2794 & -0.2687 & -0.2841 & -0.3674 & 0.2699 & -0.0119 & -0.5228 & $0.546 * *$ \\
\hline $\begin{array}{l}\text { * Signi } \\
\text { rp- corr } \\
\text { DFF - } \\
\text { DM - } \\
\text { RP - } \\
\text { PHT - } \\
\text { NBP - }\end{array}$ & $\begin{array}{l}\text { th at } 5 \% \text { pr } \\
\text { on with se } \\
\text { Days to } \\
\text { Days to } \\
\text { Reprody } \\
\text { Plant he } \\
\text { Number }\end{array}$ & $\begin{array}{l}\text { ability } \\
\text { yield per } \mathrm{p} \\
0 \% \text { flowerin } \\
\text { haturity } \\
\text { tive period } \\
\text { ht }(\mathrm{cm}) \\
\text { f branches }\end{array}$ & plant & $\begin{array}{c}\text { ** Signifi } \\
\text { Bold figu } \\
\text { NPP - } \\
\text { NCP - } \\
\text { NSP - } \\
\text { PL - } \\
\text { HSW - }\end{array}$ & $\begin{array}{l}\text { ant at } 1 \% \text { pr } \\
\text { es represent } \\
\text { Number } \\
\text { Number } \\
\text { Number } \\
\text { Pod len } \\
100 \text {-see }\end{array}$ & $\begin{array}{l}\text { oability } \\
\text { direct effect } \\
\text { f pods per } \\
\text { f clusters p } \\
\text { f seeds per } \\
\text { h (cm) } \\
\text { weight }(\mathrm{g})\end{array}$ & $\begin{array}{l}\text { ant } \\
\text { plant } \\
\text { od }\end{array}$ & & & & \\
\hline
\end{tabular}


The results of phenotypic correlations on pooled data over six environments (Table-2) revealed that seed yield per plant was significant and positively associated with plant height, number branches per plant, number of pods per plant, clusters per plant, pod length and 100-seed weight and nonsignificant positive association with days to 50 per cent flowering and number of seeds per pod and non-significant negative association with days to maturity and reproductive period. With respect to association among the component traits, days to 50 per cent flowering recorded significant positive association with days to maturity and pod length, but showed non-significant negative association with plant height and clusters per plant. The relationship between days to maturity and reproductive period, was significantly positive. Plant height showed significant positive association with number of branches per plant, pods per plant, clusters per plant, seeds per pod and pod length. The important yield related traits like branches per plant, pods per plant and clusters per plant exhibited significant positive association among themselves. Pods per plant recorded very high significant positive association with seed yield per plant followed by branches per plant and clusters per plant. The cluster per plant showed significant positive association with pod length and 100-seed weight. Seeds per pod showed significant positive association with pod length and significant negative association with 100-seed weight. Hundred seed weight exhibited positive association with seed yield per plant. Similar positive and significant association of seed yield with different quantitative traits were also reported in blackgram by Konda et al. (2008), Kumar et al., (2015), Mohanlal et al., (2018).

The phenotypic correlation coefficients of different quantitative traits with seed yield were subjected to path coefficient analysis for estimating direct and indirect effects of component traits on seed yield, which was considered as dependent variable for analysis. The direct and indirect effects of various traits on seed yield per plant pooled over seasons are given in Table-3. Path coefficient analysis pooled over six environments revealed that, plant height, number of branches and number of pods had higher magnitude of direct effect on seed yield. The association of days to 50 per cent flowering and seed yield per plant was positive and non-significant but direct effect of this trait was also found to be positive and low in magnitude (0.1451) and indirect effects via days to maturity was also positive. The days to maturity showed nonsignificant negative correlation with seed yield per plant and its direct effect on seed yield per plant was also negative (-0.2518). The reproductive period displayed nonsignificant negative correlation with seed yield per plant $(-0.104)$ but it had positive direct effect on seed yield per plant $(0.1616)$ and its indirect effects via days to maturity (0.1437) were positive. The plant height showed significant positive correlation with seed yield per plant and its direct and indirect effects on seed yield per plant were of positive with higher magnitude. The number of branches showed significant positive correlation with seed yield per plant and its direct effect was positive (0.6270) and high and its indirect effects via other traits were also found positive and high. The number of pods had significant positive correlation with seed yield per plant coupled with high positive direct effect (1.9639). The indirect effects of this trait via plant height, number of branches and number of clusters was also found to be positive and high. The number of clusters had significant positive correlation with seed yield per plant but showed negative direct effect with high magnitude (-1.0646). The number of seeds per pod exhibited nonsignificant positive correlation with seed yield per plant but its direct effect was negative (- 
0.3521). Hundred seed weight had significant positive correlation with seed yield per plant but showed negative direct effect of -0.5228 on seed yield per plant. High positive direct effects for some of these characters branches per plant, pods per plant, cluster per plant and plant height were reported by earlier workers (Konda et al., 2008; Parveen et al., 2011).

The characters which showed high positive correlation with yield like branches per plant, clusters per plant, pods per plant showed high positive direct effects on yield. These results implied the association of these characters with yield was more valuable. Moreover, the indirect effects of these characters through each other are also positive and high indicating the inter-dependent interactions of these characters to form yield. Therefore, due emphasis should be given to these traits in the selection programme to evolve high yielding blackgram genotypes suitable for different seasons.

\section{References}

Anonymous, 2017, Pulses in India: Retrospect and Prospects: Directorate of pulses development, GOI, Bhopal, India.

Burton, G. W. and Devane, E. M., 1953, Estimating heritability in tall fescue (Festecd cirunclindcede) from replicated clonal material. Agron. J., 45: 478-481.

Dewey, D. R. and Lu, K. N., 1959, A correlation and path coefficient analysis of components of crested wheat grass seed production. Agron. J., 51: 515-518.

Gartan, S. L and Sood, B. C., 1996, Relative contribution of various yield components in urdbean. Indian J. of Pulses Res., 9: 11-13.

Konda, C. R., Salimath, P. M. and Mishra, M., 2008, Correlation and path coefficient analysis in blackgram (Vigna mungo (L.) Hepper). Legume Res., 31(3): 202-205.

Kumar, G.V.,Vanaja, M., Sathish, P., Vagheera, P. and Jyothiakhsmi,N., 2015, Correlation analysis for quantitative traits in blackgram (Vigna mungo (L.) Hepper) in different seasons. Int. J. of Scientific and Res. Publications, 5 (4): 111.

Kumar, R., Kant, R. and Ojha, C.B., 2004, Character association and cause of effect analysis for spring season genotypes of mungbean. Legume Res., 27:32-36.

Mohanlal, V. A. and Saravanan, K.T. and Sabesan, T., 2018, studies on genetic correlation and path coefficient analysis of blackgram (Vigna mungo [1.] hepper) genotypes under salinity. Journal of phytology, 10: 9-11.

Parveen, S. I., Sekhar, R., Mohan, R. D. and Sudhakar, P., 2011, Correlation and path coefficient analysis for yield and yield components in blackgram (Vigna mungo (L.) Hepper). Int. J. of Appl. Bio. and Pharmaceutical Tech., 2 (3) : 619-625

\section{How to cite this article:}

Sidramappa, P. H. Kuchanur, M. Shobharani, B. Arunkumar, S. A. Kulkarni, H. C. Sowmya, D. Sheela, Laxuman and Bharati, S. 2020. Correlation and Path Coefficient Analysis in Blackgram [Vigna mungo (L.) Hepper] Across Seasons. Int.J.Curr.Microbiol.App.Sci. 9(10): 873-878. doi: https://doi.org/10.20546/ijcmas.2020.910.104 